\title{
Bankruptcy forecasting of hotel companies in the Republic of Serbia using Altman's Z-score model
}

\author{
Marko Milašinović ${ }^{1 *}$, Snežana Knežević ${ }^{2}$, Aleksandra Mitrović ${ }^{1}$ \\ ${ }^{1}$ University of Kragujevac, Faculty of Hotel Management and Tourism in Vrnjačka Banja, \\ Serbia \\ ${ }^{2}$ University of Belgrade, Faculty of Organizational Science, Belgrade, Serbia
}

\begin{abstract}
Monitoring the financial health of a company to prevent bankruptcy is not only a matter of interest to owners, management and creditors as previously thought, but also a subject of interest to the wider community due to the consequences that bankruptcy may cause. There are numerous models for predicting bankruptcy, but one of the most commonly used is Altman's Z-score model. Over time, the model has been modified so that from its initial form that was intended solely for one enterprise model, today we have a model that can be applied to manufacturing, service, public and private enterprises, as well as to businesses operating in developing markets. The paper uses Altman's Z-score model for companies operating in developing markets to assess the financial health, that is, the possibility of bankruptcy in a sample of 7 hotel companies listed on the Belgrade Stock Exchange.
\end{abstract}

Keywords: bankruptcy, financial health, Altman's Z-score model, hotel companies, Belgrade Stock Exchange

JEL classification: M41, G32, G33

\section{Predviđanje bankrotstva hotelskih preduzeća u Republici Srbiji primenom Altmanovog Z-score modela}

Sažetak: Praćenje finansijskog zdravlja preduzeća radi sprečavanja nastupanje bankrotstva, nije samo predmet interesovanja vlasnika, menadžmenta i kreditora kako se nekad mislilo, već je predmet interesovanja i šire društvene zajednice zbog posledica koje bankrotstvo može da izazove. Postoje brojni modeli za predviđanje nastanka bankrotstva preduzeća, ali jedan od najčešće korišćenih jeste Altmanov Z-score model. Vremenom je model modifikovan, tako da od početnog oblika koji je bio namanjen isključivo za proizvodna preduzeća, danas imamo model koji se može primenjivati kako za proizvodna, tako i za uslužna javna i privatna preduzeća, kao i za preduzeća koja posluju na tržištima u razvoju. U radu je korišćen Altmanov Z-score model za preduzeća koja posluju na tržištima u razvoju kako bi se ocenilo finansijsko zdravlje, odnosno mogućnost nastanka bankrotstva kod uzorka od 7 hotelskih preduzeća čije akcije su kotirane na Beogradskoj berzi.

Ključne reči: bankrotstvo, finansijsko zdravlje, Altmanov Z-score model, hotelska preduzeća, Beogradska berza

JEL klasifikacija: M41, G32, G33

* marko.milasinovic@kg.ac.rs 


\section{Introduction}

Bankruptcy is a state of insolvency in which an enterprise is unable to repay a creditor the amount of debt, whereby a situation will arise when the value of the debt is higher than the value of the property. The ability to predict bankruptcy is an important issue for many users of financial statements, such as banks, investors, rating agencies, auditors, insurance companies, and legislators (Lifschutz \& Jacobi, 2010). Financial statements are one of the key sources of information for all users, so it is crucial that they are reviewed and analyzed in more detail (Mitrović \& Vučić, 2015; Vasilev et al., 2019). According to Grammatikos (1984), bankruptcy forecasting models are valuable tools for assessing the financial health of a business by creditors, analysts, and managers. All bankruptcy forecasting models are based on the assumption that firms exhibit symptoms of bankruptcy (such as liquidity problems, troubling amounts of net working capital and problems with return on invested capital) before they arise (Stankova \& Hampel, 2018). There are numerous models for predicting bankruptcy. Bellovary et al. (2007) in their discussion regarding bankruptcy prediction models reveal that the most commonly one used is Altman's Z-score model.

The paper discusses the application of Altman's Z-score model for predicting bankruptcy of enterprises, a modified original version, which can be used for manufacturing and nonmanufacturing enterprises, as well as for companies operating in developing markets. In this paper, a sample consists of 7 hotel companies whose shares are listed on the Belgrade Stock Exchange within the sector I-Accommodation and Food Services. Initially, a review of the literature that discusses the theoretical basis of Altman's Z-score model is given. In the next section, a review of the literature is presented, followed by the methodology and data used in the research. The results and discussion consider the results of a study of bankruptcy prediction using Altman's Z-score model.

\section{Altman's Z-score model}

\subsection{Theoretical basis}

The Z-score model was developed by American professor Edward I. Altman in 1968. The model was derived from a multivariate study of the relationship between financial indicators and the likelihood of bankruptcy on a sample of 66 manufacturing companies whose shares were traded on the stock market by dividing them into two groups (the first group consisted of 33 companies that operated stable in the period from 1946 to 1965, while the second group consisted of as many companies that were the subject of bankruptcy proceedings in the same observation period). At the beginning of the research, Altman identified 22 indicators that he considered significant in predicting the bankruptcy of a business, and eventually came up with 5 financial indicators that were relevant in the process of bankruptcy forecasting, obtaining the Z-score model. However, in order to emphasize the importance of each of the 5 indicators in predicting bankruptcy, they were assigned an appropriate weighting (the higher weighting value the higher significance and vice versa). Based on this, the original Altman Z-score model can be calculated using the following formula:

$$
Z=1,2 T_{1}+1,4 T_{2}+3,3 T_{3}+0,6 T_{4}+0,999 T_{5}
$$

Where:

$$
T_{1}=\frac{\text { Net current assets }}{\text { Total assets }}
$$


The indicator of the ratio between net current assets and total assets $\left(T_{1}\right)$ is a good test of the financial "stress" of an enterprise (Knežević et al., 2019a), which is classified as liquidity indicator (Ivaniš \& Popović, 2019). The company should strive to keep the value of net current assets positive and as high as possible, since this will indicate that the company is able to pay its due short-term liabilities, that is, its liquidity is not threatened. The companies that generate business losses over a longer period will result in a decrease in the value of current assets relative to total assets (Saini, 2018).

$$
T_{2}=\frac{\text { Retained earning }}{\text { Total assets }}
$$

Indicator $T_{2}$ indicates the amount of reinvested earnings over time, that is, how much capital investments were financed from own resources. A lower value of the indicator points to greater financing from borrowings in relation to retained earnings. The value of the indicator also depends on the age of the enterprise, namely for young enterprises the indicator will have a lower value of unallocated profit compared to enterprises staying in business longer.

$$
T_{3}=\frac{\text { Profit before interest and taxes }(\text { EBIT })}{\text { Total assets }}
$$

Indicator $T_{3}$ points to the enterprise's ability to profit from its assets before paying interest and taxes, thus indicating the true productivity of the company's invested assets (as EBIT is most often the difference between operating income and operating expenses) while neglecting the amount of taxes and the structure of the source of financing the enterprise (Lekić et al., 2018; Knežević et al., 2019b).

$$
T_{4}=\frac{\text { Market value of capital }}{\text { Total liabilities }}
$$

It shows how much the market value of an enterprise can be reduced before the amount of liabilities exceeds the amount of assets, when the enterprise becomes insolvent. The market value is obtained as the sum of the market value of the ordinary and the market value of the preferred shares, while the total liabilities represent the sum of the short-term and long-term liabilities.

$$
T_{5}=\frac{\text { Sales revenues }}{\text { Total assets }}
$$

The ratio between sales revenue and total assets or the ratio of turnover of assets shows the efficiency of the company in generating sales revenue.

Based on the obtained Z-score value, a company can be classified into one of three zones:

Z > 2.99 - "safe zone", indicating that the company has a good financial situation (financially sound), that is, the insolvency of the company is low.

$1.81<\mathrm{Z}<2.99$ - "gray zone"; the company has financial problems that can lead to bankruptcy but with adequate business decisions it can be avoided it. If there is a delay in decision-making, the company may go bankrupt.

$\mathrm{Z}<1.81$ - "undesirable (problematic) zone”; the company that is likely to go bankrupt in the coming period.

According to Altman (1968), due to the increase in the time to predict bankruptcy of the company, the error is more likely to occur, that is, if the model uses data one year before the 
bankruptcy, reliability is $95 \%$, in two years $75 \%$, in three $48 \%$, in four $36 \%$ and in five years only $29 \%$. In addition to the reduced precision of the model, the lack of the original model can be regarded as being intended only for production companies, and more precisely for those whose shares are listed on the stock market. This resulted in two modifications to the original model.

The first modification was made in 1983, which enabled the application of the Z-score model to private companies (i.e. companies not listed on the stock market). The modification refers to a change in $T_{4}$ indicator, where the book value of equity is used in the numerator instead of the market value of capital, and there is a change in the value of the weights. Therefore, the "new" model takes the form:

$$
Z=0,717 T_{1}+0,847 T_{2}+3,107 T_{3}+0,420 T_{4}+0,998 T_{5}
$$

The change was also reflected in limit values, so companies with a $\mathrm{Z}$ above 2.9 could be said to operate in a safe zone. The companies operate in the gray zone if they have a $\mathrm{Z}$ score of 1.24 up to 2.89, while companies threatened with bankruptcy have a Z-score below 1.23.

The second modification made it possible to apply bankruptcy prediction models to both manufacturing and non-manufacturing enterprises, as well as to companies operating in developing markets. Indicator $T_{5}$ was excluded from the original model because it showed the greatest deviations for individual activities (Zenzerović \& Peruško, 2006; VlaovićBegović et al., 2014). A value of 3.25 was also added, so the model takes the following form:

$$
Z=3,25+6,56 T_{1}+3,26 T_{2}+6,72 T_{3}+1,05 T_{4}
$$

For financially successful companies, the Z-score is higher than 2.6; for companies operating in the gray zone the value ranges between 1.11 and 2.59, while for financially unsuccessful companies, i.e. those threatened with bankruptcy, that value is less than 1,1 . On the other hand, companies operating in developing markets will be in the safe zone if $Z>5.85$, in the gray zone, if $\mathrm{Z}$ is in the interval 3.75-5.85, while they will be in the problematic zone if $\mathrm{Z}$ $<3.75$.

\subsection{Literature review}

The use of the Z-score in bankruptcy forecasting and in assessing the financial health of companies has been the subject of many studies. It has been used to predict the bankruptcy of companies in the field of heavy processing industry and many other activities. Ramaratnam and Jayaraman (2010) conducted a study measuring the financial stability of the Indian steel industry using the Z-score model for the period 2006-2010. The study found that all 5 observed companies were financially sound. Mohamed (2016) conducted an analysis of the financial health of Oman's Cement Company SAOG, as well as its affiliates, and concluded that the company is characterized by high financial stability (i.e. has a value of $Z>3$ in the observed period), except for a few years. Using Altman's Z-score model, Panigrahi (2019) concluded that the pharmaceutical industry was financially sound in the period 2012-2017, since the average value of $\mathrm{Z}$ was 5.90. Altman's model can also be applied to the agrarian sector. Thus, Kiaupaite-Grushniene (2016) conducts a case study of three Lithuanian agricultural enterprises in the period 2010-2016, which showed that, due to the proper implementation of the restructuring process, the bankruptcy zone is approaching the gray zone, while in the other two companies high value of the $\mathrm{Z}$ indicator has been recorded (although one company has just started operating in the last two years of the observed period). The same model was also applied in predicting the bankruptcy of financial 
institutions, primarily banks. Khaddafi et al. (2017) performed the assessment of the bankruptcy of 29 banks listed on the Indonesian Stock Exchange from 2011 to 2013 and the result is that in all three observed years, 14 banks were exposed to bankruptcy occurrence, while in 2011, the number of healthy banks was 13 and the number of banks operating in the "gray" zone was 2. In the following year, the number of healthy banks was reduced to 10 , and in 2013, 11 banks were "healthy".

It can also be applied to service companies. Thus, Diakomihalis (2012) deals with the study of bankruptcy of hotels of different categories in Greece. It has been found that 3- and 5-star hotels are more at risk of bankruptcy than 4-star hotels, while 2-star hotels are at a lower risk. Mizdraković et al. (2015) found that there has been deterioration in the financial stability of hotel businesses in 2008-2011 in the Republic of Serbia, while the average value of Altman's Z-score model in 2011 compared to 2008 decreased by about $70 \%$.

\section{Methodology and data used in the research}

The paper analyzes the value movement of the Z-score model for hotel companies in the Republic of Serbia, applying the Z-score model for manufacturing and non-manufacturing businesses operating in developing markets. The sample consists of 7 hotel companies whose shares are listed on the Belgrade Stock Exchange within the sector of I-Accommodation and Catering Services, with the criterion for selection being the company with information on market capitalization available higher than RSD 100 million on 4 October 2019. These are the following companies together with their market capitalization amounts: Putnik s.c. Belgrade (RSD 725,930,458), Rimex s.c. Belgrade (RSD 454,535,800), Sloga s.c. Užice (RSD 317,051,504), Excelsior s.c. Belgrade (RSD 287,365,500), Lepenski Vir s.c. Pećinci (RSD 269,108,840), Hotel Park s.c. Novi Sad (RSD 215,281,560) and HUP Evropa s.c. Surdulica (RSD 187,916,058).

The research was conducted based on the financial statements of the companies available on the website of the Agency for Business Registers, covering the years 2014, 2015, 2016, 2017 and 2018. However, as Hotel Park Hotel s.c. Novi Sad in the first four years of observation experienced a loss above the amount of its own capital, it was excluded from the analysis (it has no practical value for further research using the Z-score model).

\section{Results and discussion}

Table 1 shows the values of the Z-score model for the observed enterprises in 2014-2018 and Figure 1 shows the dynamics of the value movement of the Z-score model for the observed enterprises in the same period.

Table 1: The value of the Z-score model

\begin{tabular}{|l|r|r|r|r|r|}
\hline \multicolumn{1}{|c|}{ The name of the hotel company } & $\mathbf{2 0 1 4}$ & $\mathbf{2 0 1 5}$ & $\mathbf{2 0 1 6}$ & $\mathbf{2 0 1 7}$ & $\mathbf{2 0 1 8}$ \\
\hline Putnik s.c. Belgrade & 3.70 & 4.21 & 1.59 & 3.74 & 3.91 \\
\hline Rimex s.c. Belgrade & 18.80 & 22.25 & 35.61 & 14.31 & 18.22 \\
\hline Excelsior s.c. Belgrade & 5.54 & 6.01 & 5.59 & 6.00 & 4.26 \\
\hline Lepenski Vir s.c. Pećinci & 3.74 & 3.90 & 4.67 & 5.04 & 4.30 \\
\hline Sloga s.c. Užice & 13.08 & 9.93 & 13.00 & 11.54 & 11.19 \\
\hline HUP Evropa s.c. Surdulica & 15.03 & 12.34 & 6.15 & 5.10 & 7.15 \\
\hline
\end{tabular}

Source: Authors' research based on the companies' financial statements 
Figure 1: Dynamics of movement of the Z-score model value

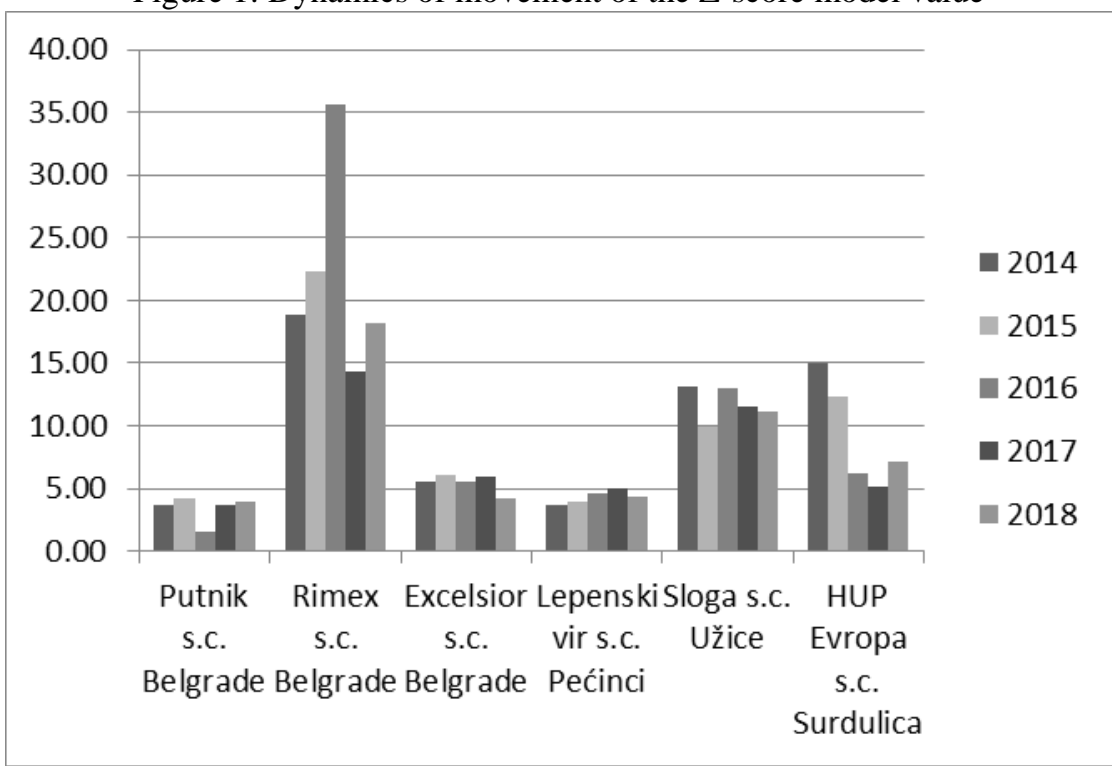

Source: Authors' research based on the companies' financial statements

In the first surveyed year (2014), 3 hotel companies were in the "safe zone", one in the "gray", while two companies were in the "problematic zone”. In 2015, one company moved from "gray" to "safe zone", while two companies moved from "problematic" to "gray zone", so that in that year, 4 hotel companies were in "safe zone" and 2 in "gray zone". In 2016, 3 companies were in the "safe", 2 in the "gray" while 1 was in the "problematic zone". Three companies in 2017 were in the "safe" zone, two in the "gray" and one in the "problematic" zone. In the last observed year, 3 companies were in the "safe" and as many in the "gray" zone.

It can be observed from Table 1, as well as from Figure 1, that at Rimex s.c. Belgrade the value of the Z-score is higher than the value of the indicators of other observed enterprises in the observed years, the difference being most pronounced in 2015 and 2016. This indicates the good financial health of the company, therefore further attention in the paper will be directed to the analysis of the elements of the Z-score model of this company.

Table 2 shows the value of components of the Z-score model of the company that achieved the highest values of the Z-score indicator in the observed period.

Table 2: Values of Z-score components of Rimex s.c. Belgrade

\begin{tabular}{|l|c|c|c|c|c|}
\hline Financial indicators & $\mathbf{2 0 1 4}$ & $\mathbf{2 0 1 5}$ & $\mathbf{2 0 1 6}$ & $\mathbf{2 0 1 7}$ & $\mathbf{2 0 1 8}$ \\
\hline T1=Working capital/Total assets & 0.11 & 0.12 & 0.16 & 0.18 & 0.16 \\
\hline T2=Retained earnings/Total assets & 0.12 & 0.15 & 0.18 & 0.22 & 0.26 \\
\hline T3=EBIT/Total assets & 0.03 & 0.04 & 0.03 & -0.02 & -0.04 \\
\hline T4=Book value of equity/Total liabilities & 13.55 & 16.67 & 29.11 & 8.77 & 13.40 \\
\hline Z-score & 18.80 & 22.28 & 35.61 & 14.23 & 18.91 \\
\hline
\end{tabular}

Source: Authors' research based on the company's financial statements

Table 2 shows that the value of the Z-score model of the observed company is at a very high level over the 5 years of observation (much higher than the threshold of 5.85 that the 
company had to cross in order to be in the "safe" zone), indicating that it is a financially sound and stable company that does not face bankruptcy in the coming period. The values of the individual components of the model are shown below.

Table 3: Ratio of Net Current Assets and Total Assets of Rimex s.c. Belgrade

\begin{tabular}{|l|r|r|r|r|r|}
\hline Elements & \multicolumn{1}{|c|}{$\mathbf{2 0 1 4}$} & \multicolumn{1}{c|}{$\mathbf{2 0 1 5}$} & \multicolumn{1}{c|}{$\mathbf{2 0 1 6}$} & \multicolumn{1}{c|}{$\mathbf{2 0 1 7}$} & \multicolumn{1}{c|}{$\mathbf{2 0 1 8}$} \\
\hline Working capital (RSD 000) & 55,865 & 64,794 & 83,413 & 80,482 & 57,709 \\
\hline Total assets (RSD 000) & 525,619 & 533.383 & 537,704 & 440,473 & 366,700 \\
\hline T1 & 0.11 & 0.12 & 0.16 & 0.18 & 0.16 \\
\hline
\end{tabular}

Source: Authors' research based on the company's financial statements

In the company, until 2018 there was a trend of increase in the value of $T_{1}$ indicator, and as the reason it can be taken that there was a significant increase in the value of net current assets in relation to the total assets engaged (except in 2017 when there was a decrease in the value of working capital, but it was followed by a significant decrease in the value of the total assets engaged). The presence of an increase in the value of net current assets over the period indicates that there was a greater investment in current assets relative to fixed assets.

Table 4: Ratio of Retained Earnings to Total Assets of Rimex s.c. Belgrade

\begin{tabular}{|l|r|r|r|r|r|}
\hline Elements & \multicolumn{1}{|c|}{$\mathbf{2 0 1 4}$} & \multicolumn{1}{c|}{$\mathbf{2 0 1 5}$} & \multicolumn{1}{c|}{$\mathbf{2 0 1 6}$} & \multicolumn{1}{c|}{$\mathbf{2 0 1 7}$} & \multicolumn{1}{c|}{$\mathbf{2 0 1 8}$} \\
\hline Retained earnings (RSD 000) & \multicolumn{1}{c|}{65,270} & 78,975 & 95,621 & 95,621 & 9,5621 \\
\hline Total assets (RSD 000) & 525,619 & 533,383 & 537,704 & 440,473 & 366,700 \\
\hline T2 & 0.12 & 0.15 & 0.18 & 0.22 & 0.26 \\
\hline
\end{tabular}

Source: Authors' research based on the company's financial statements

From table 4, it can be seen that the company has a trend of increasing the ratio of Retained Earnings to Total Assets. This indicates that the company is experiencing an increase in financing equity investments from retained earnings. When low profitability is present in an enterprise, a higher value of this indicator will result in an increase in the financial stability of the enterprise (Mohammed, 2016).

Table 5: Ratio of profit (loss) before tax and expense of interest and Total Assets of Rimex s.c. Belgrade

\begin{tabular}{|l|r|r|r|r|r|}
\hline Elements & \multicolumn{1}{c|}{$\mathbf{2 0 1 4}$} & \multicolumn{1}{c|}{$\mathbf{2 0 1 5}$} & \multicolumn{1}{c|}{$\mathbf{2 0 1 6}$} & \multicolumn{1}{c|}{$\mathbf{2 0 1 7}$} & \multicolumn{1}{c|}{$\mathbf{2 0 1 8}$} \\
\hline $\begin{array}{l}\text { Earnings before tax +Interest } \\
\text { expense (RSD 000) }\end{array}$ & 17,382 & 17,143 & 16,18 & -15465 & $-54,101$ \\
\hline Total assets (RSD 000) & 525,619 & 533,383 & 537,704 & 440,473 & 366,7 \\
\hline T3 & 0.03 & 0.04 & 0.03 & -0.03 & -0.15 \\
\hline
\end{tabular}

Source: Authors' research based on the company's financial statements

Since there is a decline in the value of the sum of profit (loss) before tax and interest expense, this will result in a decrease in the value of this element of the Z-score model.

Table 6: Ratio of equity and Total Liabilities of Rimex s.c. Belgrade

\begin{tabular}{|l|r|r|r|r|r|}
\hline Elements & \multicolumn{1}{|c|}{$\mathbf{2 0 1 4}$} & \multicolumn{1}{c|}{$\mathbf{2 0 1 5}$} & \multicolumn{1}{c|}{$\mathbf{2 0 1 6}$} & \multicolumn{1}{c|}{$\mathbf{2 0 1 7}$} & \multicolumn{1}{c|}{$\mathbf{2 0 1 8}$} \\
\hline Book value of equity (RSD 000) & \multicolumn{1}{|c|}{489,493} & 503,198 & 519,844 & 395,396 & 341,243 \\
\hline Total liabilities (RSD 000) & 36,126 & 30,185 & 17,860 & 45,077 & 25,457 \\
\hline T4 & 13.55 & 16.67 & 29.11 & 8.77 & 13.40 \\
\hline
\end{tabular}

Source: Authors' research based on the company's financial statements 
Table 6 shows that there was a significant decline in the values, which again experienced an increase in the last observed year.

\section{Conclusion}

This paper aimed to evaluate financial health, i.e. the possibility of bankruptcy in the hotel companies listed on the Belgrade Stock Exchange, with their market capitalization exceeding RSD 100 million, using Altman's Z-score model for companies operating in the developing markets.

Based on the model in 2014, 3 companies were in the "safe zone", one in the "gray zone" while two were in the "problematic" zone. In 2015, two companies were in "gray" while 4 were in "safe zone". In 2016, 3 companies were in the "safe", 2 in the "gray" while one was in the "problematic zone". During 2017, there were no changes compared to 2016. In the last observed year, 3 companies were in the "safe" and 3 were in the "gray" zone. In addition, a more detailed analysis of individual elements of the Z-score model was performed for the company that recorded the highest value of this indicator.

Given the importance of bankruptcy forecasting for different interest groups, the importance of using Altman's Z-score model is once again emphasized. Of particular importance is the prediction and use of this model for companies registered under the legal form of a jointstock company, whose shares are traded on stock exchanges. Therefore, the number of users, the importance of reports and the use of the model becomes even more significant as it can have a systemic impact. Further research can be conducted in this area as there are many open questions regarding bankruptcy forecasting as well as the use of Altman's Z-score model.

\section{References}

1. Altman, E. I. (1968). Financial ratios, discriminant analysis and the prediction of corporate bankruptcy. The Journal of Finance, 23(4), 589-609. https://doi.org/10.1111/j.1540-6261.1968.tb00843.x

2. Bellovary, J., Giacomino, D., \& Akers, M. (2007). A review of bankruptcy prediction studies: 1930 to present. Journal of Financial Education, 33, 1-42.

3. Diakomihalis, M. (2012). The accuracy of Altman's models in predicting hotel bankruptcy. International Journal of Accounting and Financial Reporting, 2(2), 96-113. https://doi.org/10.5296/ijafr.v2i2.2367

4. Grammatikos, T. (1984). Predicting bankruptcy of industrial firms in Greece, Spoudai Journal of Economics and Business, 34, 421-443.

5. Ivaniš, M., \& Popović, S. (2019). Altmanov Z-score model analize [Altman's Z-score model of analysis]. Ekonomija: teorija i praksa, 4(2), 47-62.

6. Khaddafi, M., Falahuddin, F., Heikal, M., \& Nandari, H. (2017). Analysis Z-score to predict bankruptcy in banks listed in Indonesia stock exchange. International Journal of Economics and Financial Issues, 7(3), 326-330.

7. Kiaupaite-Grushniene, V. (2016). Altman Z-score model for bankruptcy forecasting of the listed Lithuanian agricultural companies. 5th International Conference on Accounting, Auditing, and Taxation (ICAAT 2016) (pp. 222-234). Tallin, Estonia: Department of Accounting, Tallinn University of Technology, Estonia.

8. Knežević, S., Mitrović, A., Vujić, M., \& Grgur, A. (2019a). Analiza finansijskih izveštaja [Financial statement analysis]. Beograd: Samostalno izdanje autora.

9. Knežević, S., Lukić, R., \& Mitrović, A. (2019b). Application of non-standardized (alternative) financial metrics based on the income statement in measuring the 
performance of trade companies. Scientific Conference Accounting and audit in theory and practice (pp. 65-81). Banja Luka: Banja Luka College.

10. Lekić, N., Savić, G., Knežević, S., \& Mitrović, A. (2018). The efficiency analysis in small wineries in the Republic of Serbia. Economics of Agriculture, 65(4), 1529-1544. https://doi.org/10.5937/ekoPolj1804529L

11. Lifschutz, S., \& Jacobi, A. (2010). Predicting bankruptcy: Evidence from Israel. International Journal of Business and Management, 5(4), 133-141.

12. Mitrović, A., \& Vučić, V. (2015). Računovodstveno informisanje u funkciji podrške poslovnom odlučivanju u preduzeću [Accounting information in to support function business decision making in the company]. Menadžment u hotelijerstvu i turizmu Hotel and Tourism Management, 3(2), 89-95.

13. Mizdraković, M., Knežević, G., \& Stanić, N. (2015). Bankruptcy risk exposure of Serbian hotel in the period 2008-2012. SITCON - Tourism destination competitiveness (pp. 164-167). Belgrade: Singidunum University.

14. Mohammed, S. (2016). Bankruptcy prediction by using the Altman Z-score model in Oman: A case study of Raysut cement company SAOG and its subsidiaries. Australasian Accounting Business and Finance Journal, 10(4), 70-80. http://dx.doi.org/10.14453/aabfj.v10i4.6

15. Panigrahi, A. (2019). Validity of Altman's “Z” score model in predicting financial distress of pharmaceutical companies. NMIMS journal of economics and public policy, 4(1), 65-73.

16. Ramaratnam, M. S., \& Jayaraman, R. (2010). A study on measuring the financial soundness of select firms with special reference to Indian steel industry - An empirical view with Z score. Asian Journal of Management Research, 724-735.

17. Saini, V. (2018). Evaluating financial health of Gujarat state fertilizers through ' $Z$ ' score model. International Journal of Research - Granthaalayah, 6(7), 115-120. https://doi.org/10.5281/zenodo.1323027

18. Stankova, M., \& Hampel, D. (2018). Bankruptcy prediction of engineering companies in the EU using classification methods. Acta Universitatis Agriculturae et Silviculturae Mendelianae Brunensis, 66(5), 1347-1356. https://doi.org/10.11118/actaun201866051347

19. Vasilev, D., Cvetković, D., \& Grgur, A. (2019). Detection of fraudulent actions in the financial statements with particular emphasis on hotel companies. Menadžment $u$ hotelijerstvu i turizmu - Hotel and Tourism Management, 7(1), 115-125. https://doi.org/10.5937/menhottur1901115V

20. Vlaović-Begović, S., Momčilović, M., \& Tomašević, S. (2014). Ocena kreditnog boniteta preduzeća Z''- Score modelom [The enterprise creditworthiness evaluation By Z', Score model]. Ekonomske teme, 52(2), 193-204.

21. Zenzerović, R., \& Peruško, T. (2006). Kratki osvrt na modele za predviđanje stečaja [Short retrospection on bankruptcy prediction models]. Ekonomska istraživanja, 19(2), 132-151. 